
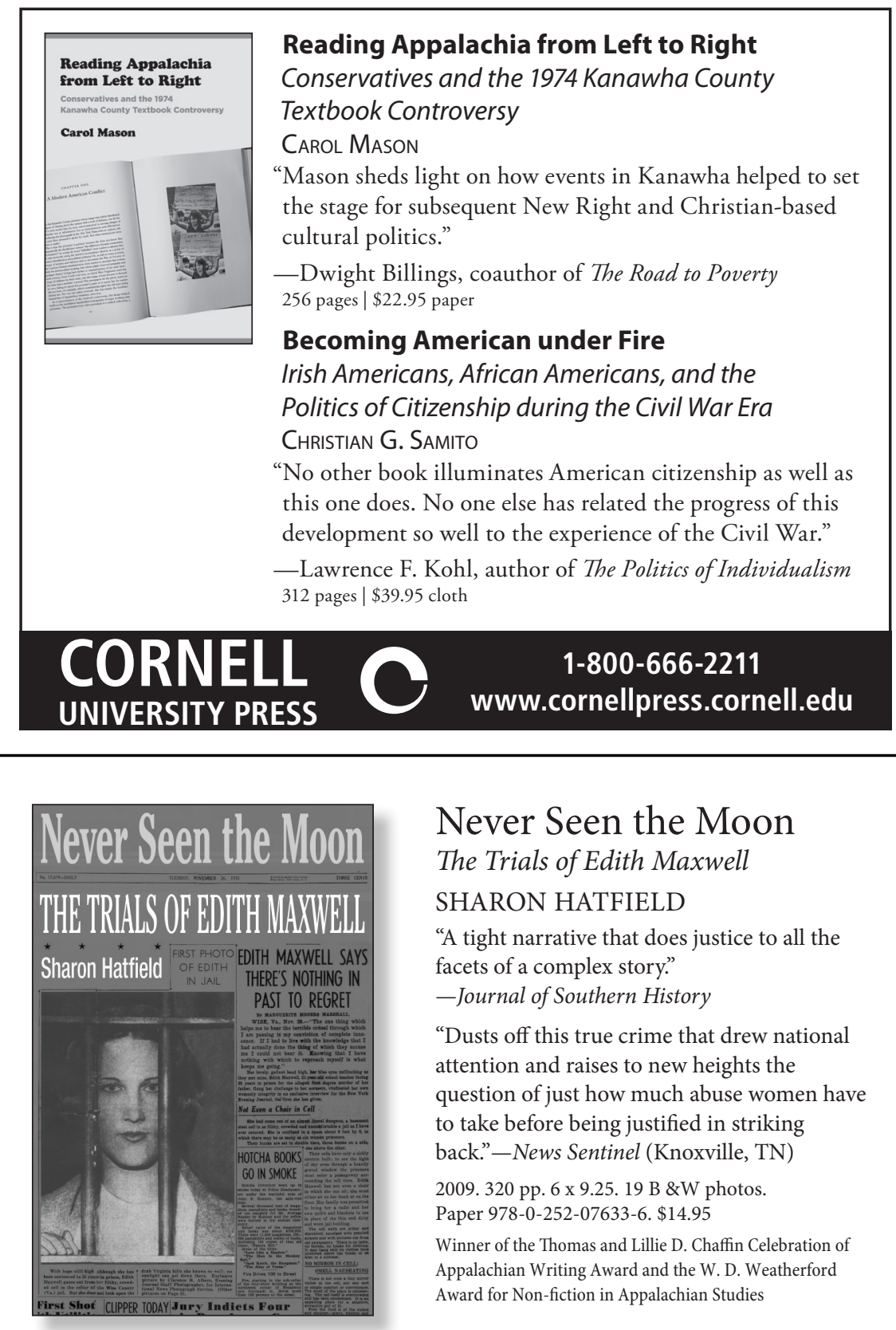

\title{
Never Seen the Moon
}

The Trials of Edith Maxwell

\section{SHARON HATFIELD}

"A tight narrative that does justice to all the facets of a complex story." -Journal of Southern History

"Dusts off this true crime that drew national attention and raises to new heights the question of just how much abuse women have to take before being justified in striking back."-News Sentinel (Knoxville, TN)

2009. 320 pp. 6 × 9.25. 19 B \&W photos.

Paper 978-0-252-07633-6. \$14.95

Winner of the Thomas and Lillie D. Chaffin Celebration of Appalachian Writing Award and the W. D. Weatherford Award for Non-fiction in Appalachian Studies 


\section{UNIVERSITY OF ILLINOIS PRESS}

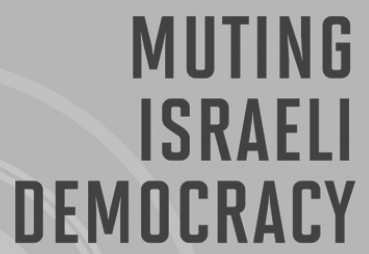

How Media and Cultural Policy Undermine Free Expression

Amit M. Schejter

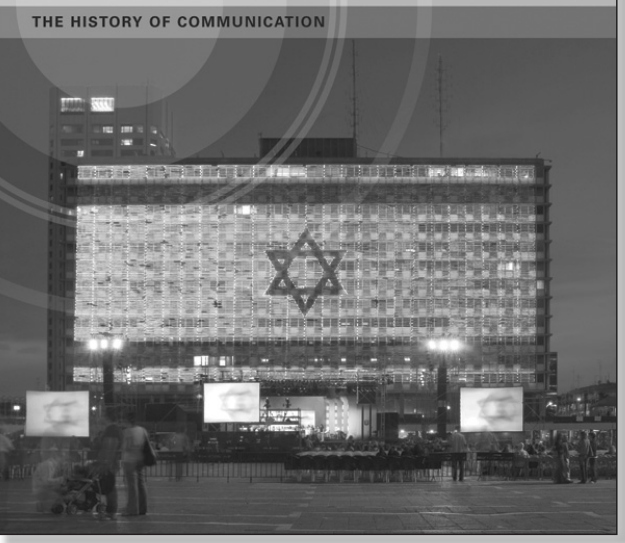

Muting Israeli Democracy

How Media and Cultural Policy Undermine Free Expression

AMIT M. SCHEJTER

"A fascinating and highly readable contribution to our understand-

ing of the fragile state of Israeli democracy. Schejter shows how painfully complex the very distinction between a democracy and a non-democracy really is." -Daniel Dor, author of The Suppression of Guilt: The Israeli Media and the Reoccupation of the West Bank

"Reassesses some of the tenets of traditional Zionist discourse and points critically to the roles that statism, cultural policies, and political economy have played in rendering the prevalent power imbalance in Israeli society." - Yaron Shemer, assistant professor of Israeli culture and modern Hebrew, University of North Carolina

192 pp. 6 × 9.3 line drawings, 7 tables. Cloth 978-0-252-03458-9. \$60.00.

Paper 978-0-252-07693-0. \$20.00

The History of Communication 


\section{$[[\cdot]]$ UNIVERSITY OF ILLINOIS PRESS}

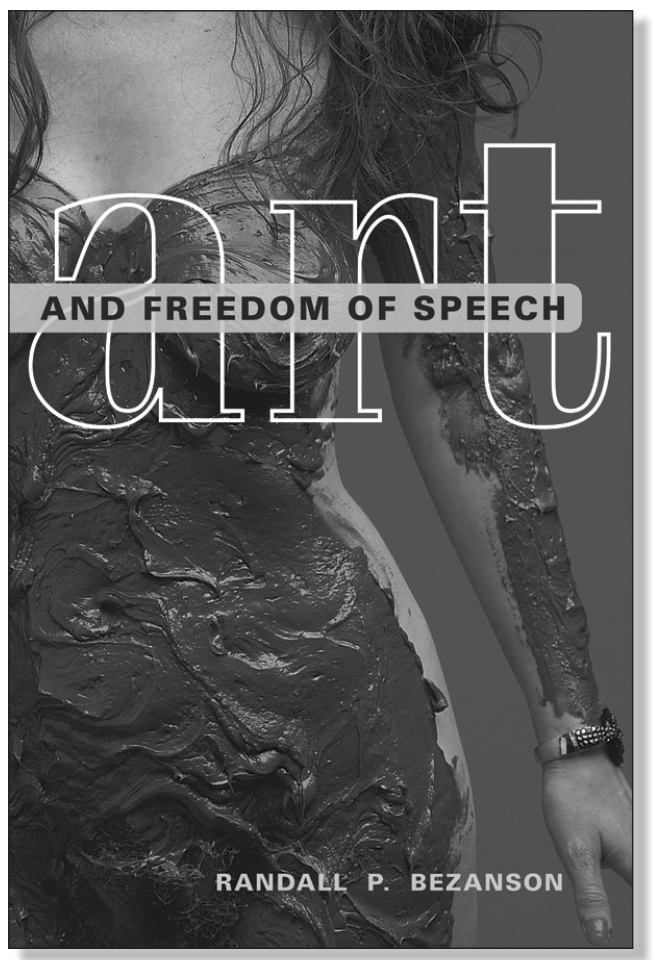

\section{Art and Freedom of Speech \\ RANDALL P. BEZANSON}

"Reaches beyond legal theory to explore the role of art as a human product, its production, consumption, and meaning. Art and Freedom of Speech represents a brilliant mind at workin a lovely, intellectually playful tone" - Linda R. Hirshman, author of Get to Work: . . . And Get a Life, Before It's Too Late "A comprehensive, in-depth examination of First Amendment principles as they pertain to the arts. Bezanson's detailed and lively analyses of Supreme Court arguments help clarify the conceptual bases of each case." - Joan DelFattore, author of The Fourth R: Conflicts Over Religion in America's Public Schools 328 pp. 6 × 9.17 black \& white photographs. Cloth 978-0-252-03443-5. \$35.00 


\section{UNIVERSITY OF ILLINOIS PRESS}

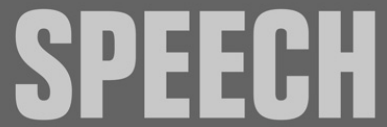

The First Amendment,

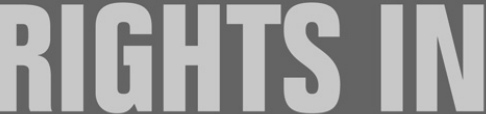

Democracy, and the Media

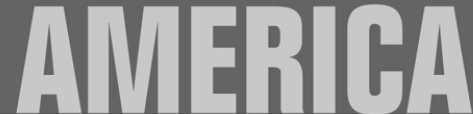

\section{LAURA STEIN}

\section{Speech Rights in America}

The First Amendment, Democracy, and the Media

\section{LAURA STEIN}

"This is a thoughtful analysis ranging over history and recent cases." - Communication Booknotes Quarterly

"The greatest strength of Speech Rights in America is Stein's ability to look through the lens of the individual.

Legal histories have been told for much too long from the omnipotent, often disconnected perspective of legal experts who tell us which case decisions are important and why. . . . The best way to get students engaged in any course material is to tell them the information is relevant to their lives. Stein does just that. She makes legal history relevant." - Journalism \& Mass Communication Educator

184 pp. 6 × 9. 1 table. Paper 978-0-252-07536-0. \$20.00

The History of Communication 


\section{American Society for Legal History}

The American Society for Legal History is a nonprofit membership organization dedicated to fostering scholarship, teaching, and study concerning the law and institutions of all legal systems, both Anglo-American and international. Founded in 1956, the Society sponsors the journal and Studies in Legal History, a series of book-length monographs available to ASLH members at substantial prepublication discounts. In addition, the Society holds an annual meeting to promote scholarship and interaction among teachers, practitioners, and students interested in legal history, and publishes a semiannual newsletter reporting developments in the field. For further information concerning the Society, please write: Thomas P. Gallanis, University of Minnesota School of Law, 326 Mondale Hall, 229-19th Avenue South, Minneapolis, MN 55455.

To become a member of the Society, please complete and mail the application to University of Illinois Press, 1325 S. Oak St., Champaign, IL 61820.

\section{Membership Application}

Please check appropriate membership below:

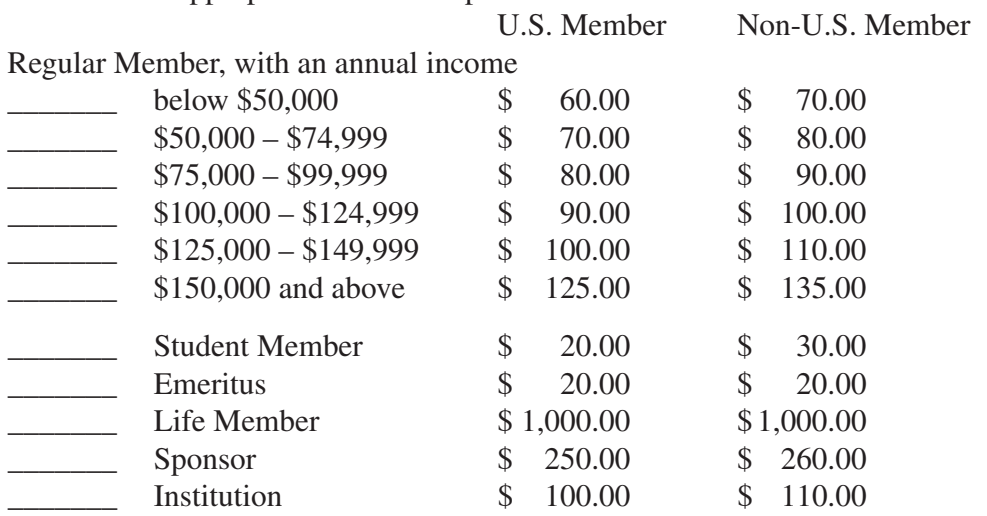

Please remit amount due in U.S. dollars drawn on a U.S. bank, payable to: University of Illinois Press.

Total Amt: \$ Visa/MC:

Acct. Name: Exp. Date:

Signed:

Name:

Institution:

Address:

City: State: Zip:

Phone (Home): (Office):

Fax: E-mail: 


\begin{tabular}{|c|c|c|}
\hline \multicolumn{3}{|c|}{ Officers, 2009} \\
\hline $\begin{array}{l}\text { Maeva Marcus } \\
\text { George Washington } \\
\text { University } \\
\text { President }\end{array}$ & $\begin{array}{l}\text { Constance Backhouse } \\
\text { University of Ottawa } \\
\text { President-elect }\end{array}$ & $\begin{array}{l}\text { Thomas P. Gallanis } \\
\text { University of Minnesota } \\
\text { Secretary } \\
\text { C E Klafter } \\
\text { University of British Columbia } \\
\text { Treasurer }\end{array}$ \\
\hline \multicolumn{3}{|c|}{ Board of Directors } \\
\hline $\begin{array}{l}\text { Lauren Benton } \\
\text { New York University }\end{array}$ & $\begin{array}{l}\text { William Forbath } \\
\text { University of Texas }\end{array}$ & $\begin{array}{l}\text { M. C. Mirow } \\
\text { Florida International } \\
\text { University }\end{array}$ \\
\hline $\begin{array}{l}\text { Alfred Brophy } \\
\text { University of North } \\
\text { Carolina }\end{array}$ & $\begin{array}{l}\text { Annette Gordon-Reed } \\
\text { New York Law School } \\
\text { Sally Hadden }\end{array}$ & $\begin{array}{l}\text { University } \\
\text { Rebecca J. Scott } \\
\text { University of Michigan }\end{array}$ \\
\hline $\begin{array}{l}\text { Christine Desan } \\
\text { Harvard University }\end{array}$ & $\begin{array}{l}\text { Florida State University } \\
\text { Martha S. Jones }\end{array}$ & $\begin{array}{l}\text { Robin Chapman Stacey } \\
\text { University of Washington }\end{array}$ \\
\hline $\begin{array}{l}\text { Charles Donahue, Jr. } \\
\text { (Immediate Past- } \\
\text { President) } \\
\text { Harvard University }\end{array}$ & $\begin{array}{l}\text { University of Michigan } \\
\text { Adam Kosto } \\
\text { Columbia University }\end{array}$ & $\begin{array}{l}\text { Karen Tani } \\
\text { (Graduate Student } \\
\text { Representative) } \\
\text { University of Pennsylvania }\end{array}$ \\
\hline $\begin{array}{l}\text { Mary Dudziak } \\
\text { University of Southern } \\
\text { California }\end{array}$ & $\begin{array}{l}\text { Michael Lobban } \\
\text { University of London }\end{array}$ & $\begin{array}{l}\text { John Wertheimer } \\
\text { Davidson College }\end{array}$ \\
\hline \multicolumn{3}{|c|}{ Publications Committee } \\
\hline $\begin{array}{l}\text { Bruce H. Mann, Chair } \\
\text { Harvard University } \\
\text { Adrienne Davis } \\
\text { University of North } \\
\text { Carolina }\end{array}$ & $\begin{array}{l}\text { Cynthia Herrup } \\
\text { University of Southern } \\
\text { California } \\
\text { William P. LaPiana } \\
\text { New York Law School }\end{array}$ & $\begin{array}{l}\text { Linda Przybyszewski } \\
\text { University of Notre Dame } \\
\text { David S. Tanenhaus } \\
\text { University of Nevada, } \\
\text { Las Vegas }\end{array}$ \\
\hline $\begin{array}{l}\text { Daniel Ernst } \\
\text { Georgetown University }\end{array}$ & $\begin{array}{l}\text { David Lieberman } \\
\text { University of California, } \\
\text { Berkeley }\end{array}$ & $\begin{array}{l}\text { Christopher Waldrep } \\
\text { California State } \\
\text { University, San Francisco }\end{array}$ \\
\hline \multicolumn{3}{|c|}{ Fellows of the American Society for Legal History } \\
\hline $\begin{array}{l}\text { Honorary Fellows } \\
\text { Morris S. Arnold } \\
\text { Morris Cohen } \\
\text { Lawrence M. Friedman } \\
\text { R. H. Helmholz }\end{array}$ & $\begin{array}{l}\text { Morton J. Horwitz } \\
\text { Harold M. Hyman } \\
\text { Laura Kalman } \\
\text { Stanley N. Katz } \\
\text { John T. Noonan, Jr. }\end{array}$ & $\begin{array}{l}\text { John Phillip Reid } \\
\text { Harry N. Scheiber } \\
\text { A. W. B. Simpson } \\
\text { W. A. J. Watson }\end{array}$ \\
\hline $\begin{array}{l}\text { Corresponding Fellows } \\
\text { J. H. Baker } \\
\text { Raoul C. Van Caenegem } \\
\text { Ennio Cortese } \\
\text { Robert Feenstra }\end{array}$ & $\begin{array}{l}\text { André Gouron } \\
\text { Paolo Grossi } \\
\text { Peter Landau } \\
\text { Anne Lefebvre-Teillard } \\
\text { Hector L. MacQueen }\end{array}$ & $\begin{array}{l}\text { S. F. C. Milsom } \\
\text { Kjell Modéer } \\
\text { Peter G. Stein } \\
\text { Michael Stolleis }\end{array}$ \\
\hline
\end{tabular}

